\title{
Experimental poisoning of goats by Ipomoea carnea subsp. fistulosa in Argentina: A clinic and pathological correlation with special consideration on the central nervous system ${ }^{1}$
}

\author{
Elvio E. Ríos ${ }^{2}$, Luciana A. Cholich², Eduardo J. Gimeno ${ }^{3}$, María G. Guidi3* \\ and Ofelia C. Acosta de Pérez ${ }^{2}$
}

\begin{abstract}
Ríos E.E., Cholich L.A., Gimeno E.J., Guidi M.G. \& Acosta de Pérez O.C. 2012. Experimental poisoning of goats by Ipomoea carnea subsp. fistulosa in Argentina: A clinic and pathological correlation with special consideration on the central nervous system. Pesquisa Veterinária Brasileira 32(1):37-42. Cátedra de Farmacología, Facultad de Ciencias Veterinarias, Universidad Nacional del Nordeste, Sargento Cabral 2139, 3400, Corrientes, Argentina. E-mail: patmed@vet.unne.edu.ar

Ipomoea carnea subsp. fistulosa, aguapei or mandiyura, is responsible for lysosomal storage in goats. The shrub contains several alkaloids, mainly swansonine which inhibits lysosomal $\alpha$-mannosidase and Golgi mannosidase II. Poisoning occurs by inhibition of these hydrolases. There is neuronal vacuolation, endocrine dysfunction, cardiovascular and gastrointestinal injury, and immune disorders. Clinical signs and pathology of the experimental poisoning of goats by Ipomoea carnea in Argentina are here described. Five goats received fresh leaves and stems of Ipomoea. At the beginning, the goats did not consume the plant, but later, it was preferred over any other forage. High dose induced rapid intoxication, whereas with low doses, the course of the toxicosis was more protracted. The goats were euthanized when they were recumbent. Cerebrum, cerebellum, medulla oblongata, pons and colliculi, were routinely processed for histology. In nine days, the following clinical signs developed: abnormal fascies, dilated nostrils and abnormal postures of the head, cephalic tremors and nystagmus, difficulty in standing. Subsequently, the goats had a tendency to fall, always to the left, with spastic convulsions. There was lack in coordination of voluntary movements due to Purkinje and deep nuclei neurons damage. The cochlear reflex originated hyperreflexia, abnormal posture, head movements and tremors. The withdrawal reflex produced flexor muscles hypersensitivity at the four legs, later depression and stupor. Abnormal responses to sounds were related to collicular lesions. Thalamic damage altered the withdrawal reflex, showing incomplete reaction. The observed cervical hair bristling was attributed to a thalamic regulated nociceptive response. Depression may be associated with agonists of lysergic acid contained in Ipomoea. These clinical signs were correlated with lesions in different parts of the CNS.
\end{abstract}

INDEX TERMS: Poisonous plants, Ipomoea carnea, plant poisoning, goats, CNS lesions, transmission electron microscopy.

RESUMO.- [Intoxicação experimental por Ipomoea carnea subsp. fistulosa em caprinos da Argentina: correlação clínico-patológica, com especial atenção ao sistema nervoso central.] Ipomoea carnea subsp. fistulosa, aguapeí

\footnotetext{
${ }^{1}$ Received on July 22, 2011.

Accepted for publication on October 5, 2011.

${ }^{2}$ Cátedra de Farmacología, Facultad de Ciencias Veterinarias, Universidad Nacional del Nordeste (UNNE), Sargento Cabral 2139, 3400 Corrientes, Argentina.

${ }^{3}$ Instituto de Patología, Facultad de Ciencias Veterinarias, Universidad Nacional de la Plata (UNLP), 60 y 118, 1900 La Plata, Buenos Aires, Argentina. *Corresponding autor: patmed@vet.unne.edu.ar
}

ou mandiyura, causa uma doença de depósito lisossomal em caprinos. A planta contém vários alcalóides, principalmente swansonine, que inibe uma $\alpha$-mannosidase lisossomal e uma mannosidase II do Golgi. A intoxicação ocorre pela inibição dessas hidrolases. Há vacuolização neuronal, disfunção endócrina, lesões cardiovasculares e gastrointestinais e distúrbios imunológicos. No presente trabalho é descrita a intoxicação experimental por Ipomoea carnea subsp. fistulosa em caprinos da Argentina. Cinco cabras receberam folhas frescas e ramos de Ipomoea. No começo eles não consumiram a planta, mas depois ela foi preferida a qualquer outras forrageiras. Altas doses induziram uma 
intoxicação rápida, enquanto que com doses baixas demora mais tempo. As cabras foram sacrificadas quando ficavam em decúbito. Cérebro, cerebelo, medula oblonga, ponte e colículos foram processados rotineiramente para histologia. Aos nove dias, encontramos: fascie anormal, narinas dilatadas, posturas anormais da cabeça, tremores cefálicos e nistagmo, dificuldade para permanecer na estação. Posteriormente, presentearam a tendência de queda, sempre à esquerda, com convulsões espásticas. Os neurônios de Purkinje e os os núcleos profundos foram danificados. Como conseqüência, emergiu a falta de coordenação de movimentos voluntários. A hiper-reflexo coclear originou postura anormal, movimentos de cabeça e tremores. A retirada produz reflexos hipersensibilidade nos flexores dos quatro membros, depois depressão e letargia. As respostas anormais estão ligadas a lesões do colículo. Injurias no tálamo alteram o reflexo de retirada, mostrando uma reação incompleta. Os pelos eriçados da região cervical podem representar uma resposta nociceptiva também regulada pelo tálamo. A depressão pode estar associada com agonistas do ácido lisérgico presentes na Ipomoea. Esses sintomas estão relacionados com lesões em diferentes partes do SNC.

TERMOS DE INDEXAÇÃO: Plantas tóxicas, Ipomoea carnea, caprinos, intoxicação por planta, CNS lesões, microscopia eletrônica de transmissão.

\section{INTRODUCTION}

Ipomoea sp. has been held responsible for severe episodes of intoxication in the tropics and subtropics. There are reports of spontaneous poisoning, especially in goats, in parts of Brazil, Sudan, India, Mozambique and Argentina (Damir et al. 1987, De Balogh et al. 1999, Rodriguez Armesto et al. 2004, Barbosa et al.2006, Antoniassi et al. 2007, Armien et al. 2007, Barbosa et al. 2007, Ríos et al. 2008). The plant contains as main toxic component swainsonine which inhibits lysosomal enzyme $\alpha$-mannosidase and mannosidase II Golgi apparatus (Colegate et al. 1979, Molyneux \& James 1982). The intoxication induces enzymatic dysfunction and the accumulation of complex oligosaccharides in lysosomes. As a consequence, vacuolation becomes evident in different cells, mainly in neurons. The alteration of glycoprotein synthesis may be associated with endocrine dysfunction, cardiovascular and gastrointestinal injury, neural and immune disorders (Hueza et al. 2003, Armien et al. 2007).

The most frequent clinical signs observed in ruminants, within the first month after ingestion of Ipomoea, consist of: lethargy, muscle tremors, hyperexcitability, dilated pupils, opisthotonus, strabismus, weakness of the hind limbs , severe incoordination, ataxia, wasting and recumbence; all primarily associated with dysfunction of the central nervous system. (Tokarnia et al. 2002, Haraguchi et al. 2003, Barbosa et al. 2006, Armien et al. 2007, Guedes et al. 2007).

Despite many reports on the poisoning of Ipomoea carnea, clinical signs and morphological lesions of poisoning have not been well characterized (Adam et al. 1973, Idris et al. 1973, Tartour et al. 1974, Damir et al. 1987, Nath \& Pathak 1995, Schumaher-Henrique et al. 2003).The aim of this paper is to describe the epidemiology, clinical signs and pathology of the experimental poisoning by Ipomoea carnea subsp. fistulosa primarily affecting the CNS of goats.

\section{MATERIALS AND METHODS}

Plant identification and toxicological analysis. Ipomoea carnea subsp. fistulosa was collected in the Capital Department, Corrientes Province, Argentina in the spring. A sample of the plant was deposited at the Institute of Botany, Faculty of Agricultural Sciences, UNNE (Corrientes, Argentina), with the number CTES395. Taxonomic identification was made by Lic. Roberto Salas Taxonomist of the Institute.

Experimental design. The experimental group consisted of five 1-3-year-old goats which had not previously been exposed to the plant. Each of these goats received $50 \mathrm{~g} / \mathrm{kg} /$ day of fresh leaves and stems of I. carnea, for 21 days. Equal numbers of goats were used as control, and received only alfalfa. Both groups received water ad libitum. During the experiment, all goats were submitted to a detailed examination of the central nervous system, including state of consciousness and sensory, facies attitudes, standing, walking and lyingdown, and reflexes. The goats were euthanized when they were recumbent and not able to eat or drink for themselves.

Histopathology. For sacrifice, animals were anesthetized with a combination of xylazine hydrochloride $2 \%$ and ketamine hydrochloride, and then, subjected to a drain "on target" and immediately proceeded to the taking of tissue, for histopathological analysis (Ethics Commission local, Faculty of Veterinary Sciences, UNNE). The CNS was serially sectioned and cut at level of thalamus, cerebellum, colliculus, pons, and medulla oblongata. Specimens were fixed in $10 \%$ neutral buffered formalin at room temperature, embedded in paraffin, sectioned at $5 \mu \mathrm{m}$, stained with hematoxylin and eosin (HE) and examined under a light microscope.

Transmission electron microscopy. Representative sections were fixed by immersion in $2 \%$ glutaraldehyde, post-fixed in osmium tetroxide and embedded in epoxy resin. Semi-thin sections ( $1 \mu \mathrm{m}$ thick and stained with $1 \%$ toluidine blue in $1 \%$ borax) were evaluated for the presence of intracytoplasmatic storage vacuoles and abnormal staining. Ultra-thin section $(60-80 \mathrm{~nm})$ of selected areas, were stained with uranyl acetate and $2 \%$ lead citrate and examined in a JEOL transmission electron microscope.

Lectin histochemistry. Representative sections of the thalamus, cerebellum and colliculi were submitted to lectin histochemistry as follows: after dewaxing, sections were treated with $0.3 \%$ hydrogen peroxide in methanol for $30 \mathrm{~min}$ at room temperature (to Inhibit the endogenous peroxidase), rinsed several times in $0.01 \mathrm{M}$ PBS (pH 7.2), and treat with $0.1 \%$ bovine serum albumin in PBS for 15 min. The sections were then incubated for 1 hour at room temperature with biotinylated lectin with different specificity. Nine lectins, with different specificity were employed: Con A (Concanavalia ensiformis, binding specificity a-D-Man and a-D-Glc), DBA (Dolichos biflorus, binding specificity a-D-GalNAc), SBA (Glycine max, binding specificity a-D-GalNAc, a-D-GalNAc and $\mathrm{a}$ and $\mathrm{b}-\mathrm{Gal}$ ), PNA (Arachis hypogaea, binding specificity $\mathrm{b}$ and $\mathrm{a}$ and a GalNAc), RCA-I (Ricinus communis-I, binding specificity -b-D-Gal and a-D-Gal), UEA-1 (Ulex europaeus-I, binding specificity a-L-Fuc), WGA (Triticum vulgaris, binding specificity a-D-GlcNAc and NeuNAc) and sWGA (succinyl WGA, binding specificity binding specificity a-D-GlcNAc and NeuNAc) LCA (Lens culinary, binding specificity a-Glc, a-D-Man) (Vector Laboratories, Burlingame, CA, USA).

The optimal lectin concentration was $30 \mathrm{mg} / \mathrm{ml}$ in PBS for all lectins, except for PNA, which was applied at a concentration 
of $10 \mathrm{mg} / \mathrm{ml}$. Later, the slides were incubated with avidin-biotin-peroxidase complex (ABC) (Vector) for $45 \mathrm{~min}$. The horseradish peroxidase was activated by incubation for 1-2 min with a commercial diaminobenzidine kit (Dako Cytomation, Carpinteria, CA, USA). Specimens were rinsed in water, dehydrated with graded ethanol solutions, cleared in xylene and mounted in Permount (Fisher Scientific International Inc., Liberty Lane Hampton, NH, USA). Controls for lectin staining included: Exposure to horseradish-peroxidase and substrate medium without the lectin, and blocking by incubation with the appropriate blocking sugars $(0.1$ to $0.2 \mathrm{M}$ in PBS) for $1 \mathrm{~h}$ at room temperature before applying to the sections. The intensity of lectin binding was scored subjectively from 0 (none) to 3 (strongly positive).

\section{RESULTS}

Plant identification and toxicological analysis. The plant was identified as Ipomoea carnea subsp. fistulosa, belonging to the family Convolvulacea, commonly known in northeastern Argentina as "aguapeí" or "mandiyura" (Fig.1).

Experimental design. Ipomoea poisoning in goats occurred after the ingestion of $50 \mathrm{~g}$ of fresh leaves/per $\mathrm{kg}$ body weight, per day, over a period of 21 days, with a total consumption of $20 \mathrm{~kg}$ of plant per goat. Clinical signs were similar in all affected animals which were not observed in control animals. After the first week of study, behavioral changes were observed; including the great preference for consumption of the plant, which was observed even when the goats had other available food (Fig.2A). Towards the end of the experiment, the goats showed depression. Despite depression and weakness, they were still eating in lateral decubitus (Fig.2B). From the day nine, all intoxicated goats showed abnormal fascies, dilated nostrils, abnormal carrying of the head and cephalic tremors, resembling denial and affirmation, with nystagmus. Additionally, there was difficulty to keep a standing position and to sit up, and but this was achieved only after several attempts (Fig.3) At the beginning of clinical signs, the goats walked with weakness of the hind limbs, or both hind limbs rigid, ataxia, and difficulty in keeping a normal lift. Subsequently, the rigidity of the limbs increased, with difficulty in maintaining the balance. Consequently, they fell always to the left, displaying marked seizures. Other signs were walking in cir-

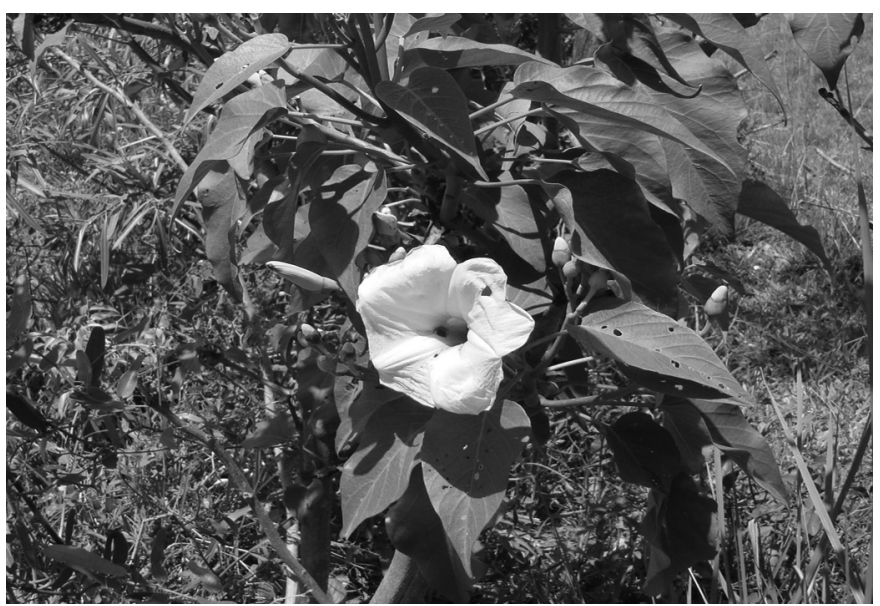

Fig.1. Ipomoea carnea subsp. fistulosa. Specimen from from Corrientes, Argentina.

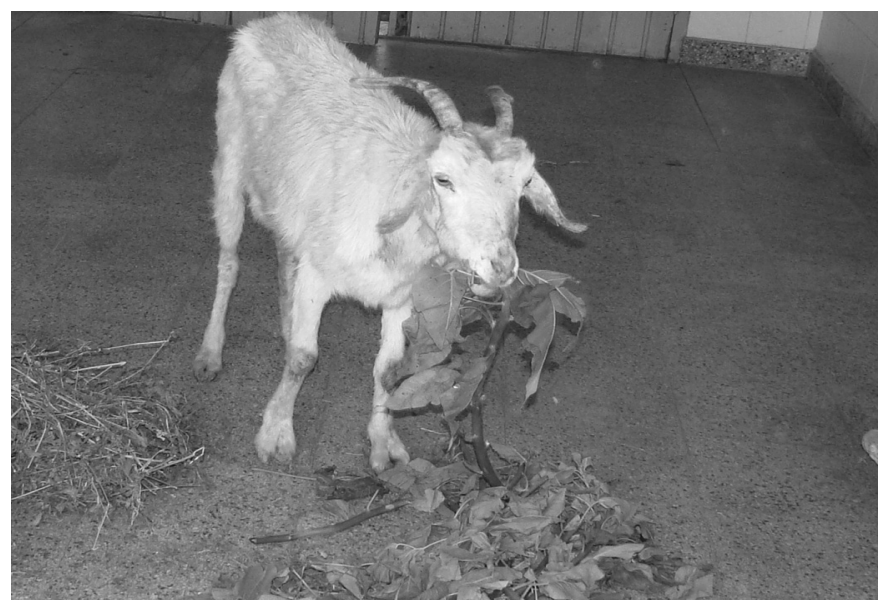

Fig.2A. Preference of goats for Ipomoea carnea consumption.

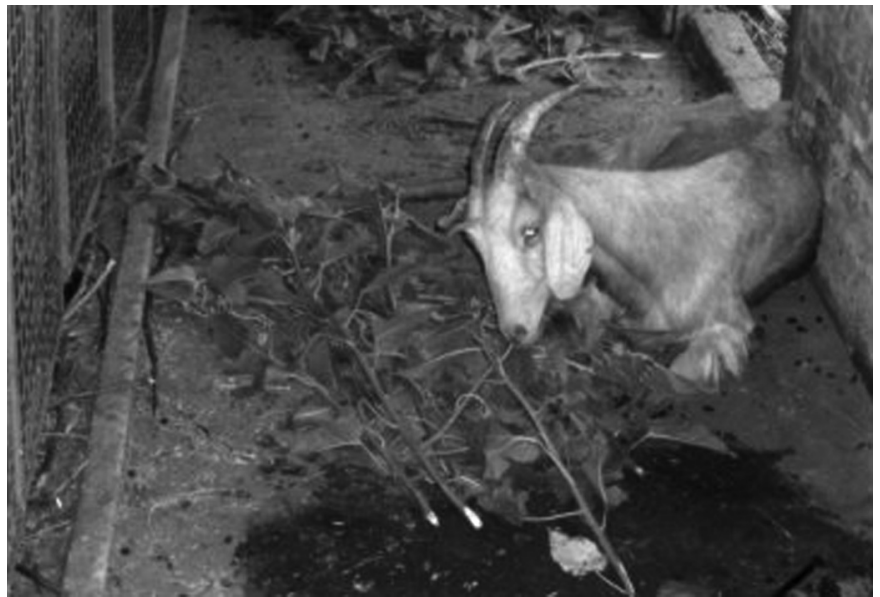

Fig.2B. Goat in advanced state of intoxication by Ipomoea carnea. Despite the clinical signs the goat was still eating the plant.

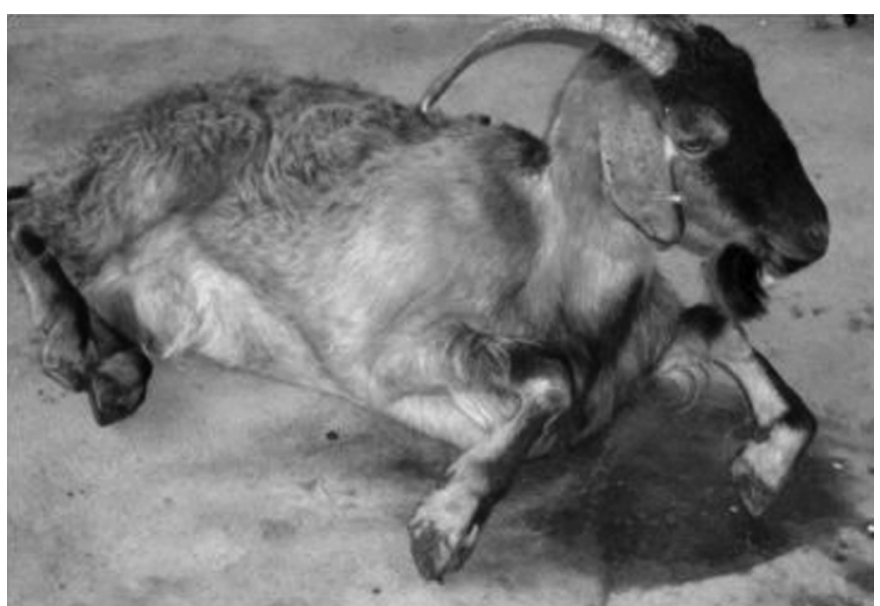

Fig.3. Goat poisoned with Ipomoea carnea showing difficulty to rise and stand.

cles, paddling and opisthotonus (Fig.4). After eleven days of intoxication, vestibulocochlear deficit was manifested in response to sound stimuli, with reflexes, posture and coordination accompanied by abnormal head movements and tremors. Also, the withdrawal reflex was altered to the end of the experiment, showing an incomplete reaction of the flexor muscles and hypersensitive to the stimulus on the 


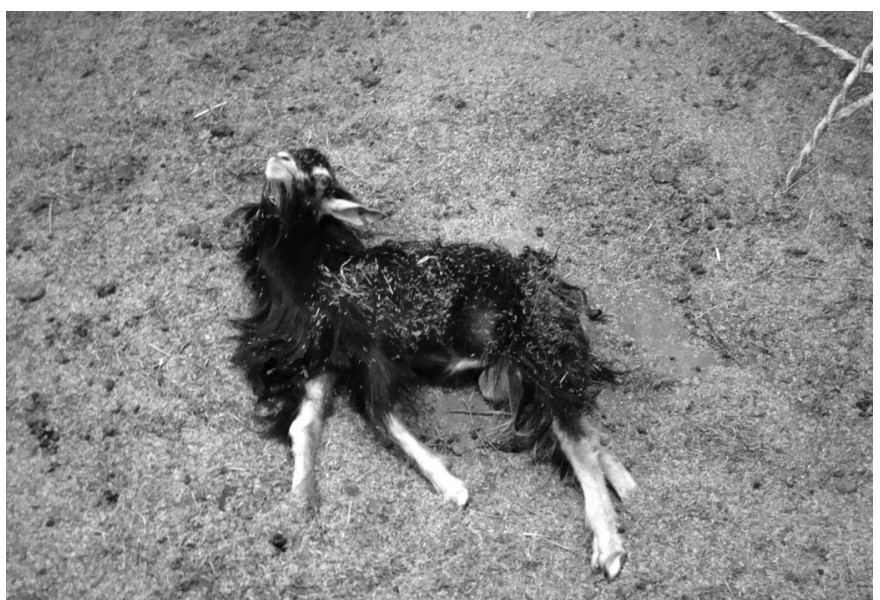

Fig.4. Intoxicated goat in left recumbence with paddling movements and opisthotonus.

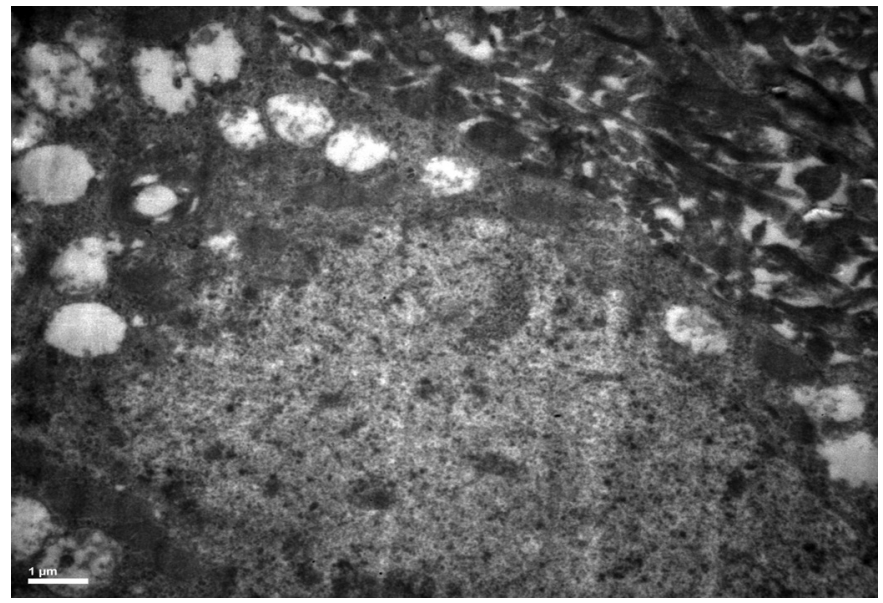

Fig.5. Thalamus from a goat poisoned by Ipomoea carnea. Neuron showing membrane-bound perycarial vacuoles. Electron microscopy. Bar: $1 \mu \mathrm{m}$.

four members. Recumbent goats maintained the appetite and even ate and drank in this position.

Histopathology. The main histological lesions were observed in neurons of the thalamus and the Purkinje cells. The perikaryon was distended with foamy cytoplasm by the presence of small vacuoles. In other sections of the CNS, it was mild to moderate vacuolation.

Transmission electron microscopy. Ultrastructurally, the cytoplasmic vacuolation was evident in neurons and astrocytes in the thalamus and Purkinje cells, most of which were optically empty and delimited by a membrane. Membrane fragments, reticular or dense granules and amorphous substances were observed in some vacuoles (Fig.5).

Lectin histochemistry. With regard to the lectinhistochemical, the vacuolated neurons and astrocytes in the thalamus and Purkinje cells reacted strongly to LCA and moderately to Con-A, sWGA and WGA. No reaction was observed with the other lectins. Additionally, cellular staining was absent in slides from control goats (Fig.6A,B)

\section{DISCUSSION AND CONCLUSION}

Clinical signs in experimentally Ipomoea carnea-intoxicated goats, were mainly neurological disorders characterized by
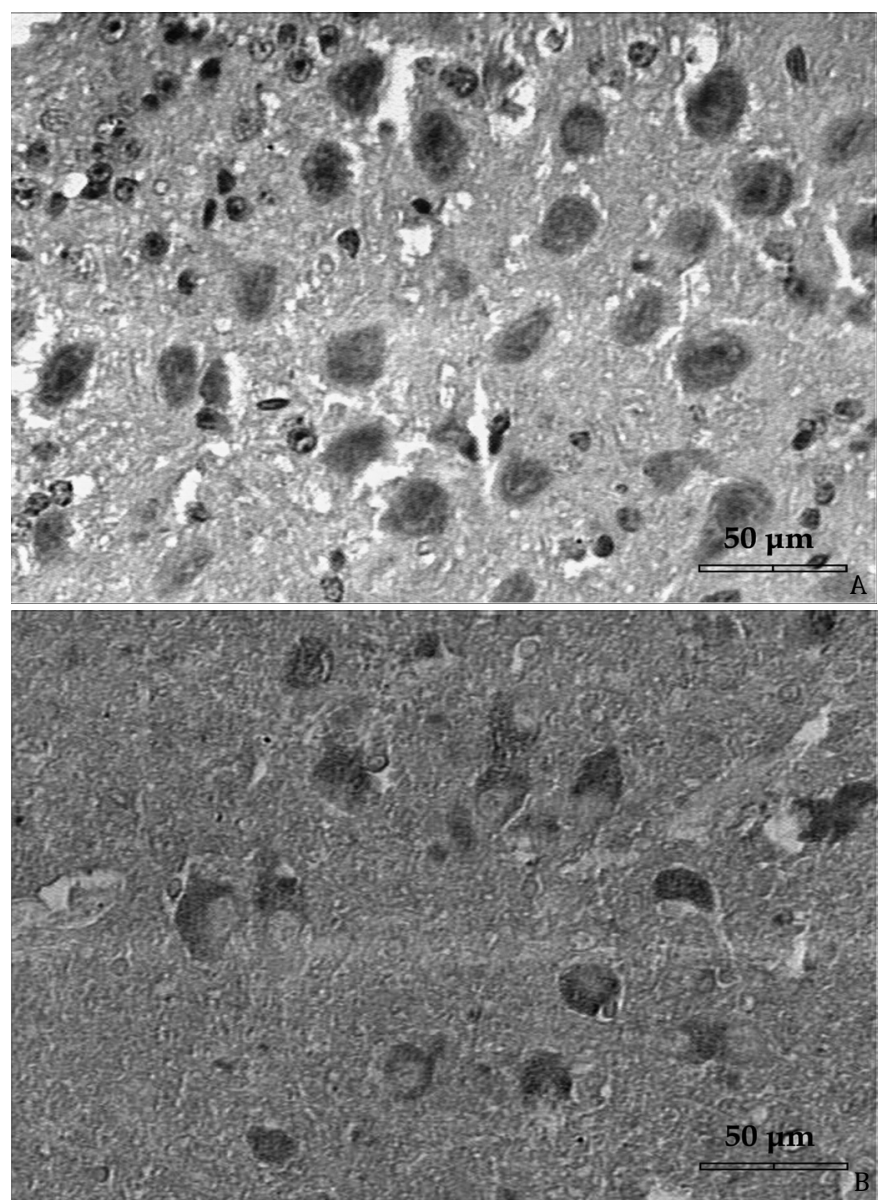

Fig.6. Lectin histochemistry. (A) Neurons in a control animal were negative for LCA. (B) Neurons in an affected goat were positive for this lectin. Avidin-Biotin Complex method. Bar: $50 \mathrm{~mm}$.

depression, weakness, tremor, nystagmus, dysmetria, ataxia, spastic paresis, increased base of support, abnormal postures, signs similar to those described by other authors in poisoning by Ipomoea sp. (Tokarnia et al. 2000, Armien et al. 2007).

Also, they resemble to what produced by other plants, containing swainsonine as active principle in goats (James et al. 1970, Dorling et al. 1980, James \& Panter 1989, Molyneux et al. 1995, De Balogh et al. 1999, Driemeier et al. 2000, Rodriguez Armesto et al. 2004, Barbosa et al. 2006, Rios et al. 2008) and also in other animals species such as cattle, sheep and buffalo (Tokarnia et al. 2000, Barbosa et al. 2005, Guedes et al. 2007, Riet-Correa \& Méndez 2007). In horses, the clinical picture is partially different, being primarily gastrointestinal (Loretti et al. 2003).

First signs were observed after one week of intoxication. In our study, we administered a high dose, which induced a rapid and early toxicity. Doses as low $5 \mathrm{~g} / \mathrm{kg}$ induce clinical signs after 100 days into the poisoning (Srilatha et al. 1993a,b). At the beginning of the experiment, the animals resisted Ipomoea consumption but after a week, it was accepted up to the point that they preferred Ipomoea leaves to alfalfa hay. Preference for the consumption has also been commonly reported in poisoning by plants containing swainsonine such as locoweeds (Ralphs et al. 1990), I. car- 
nea (Schumaher-Henrique et al. 2003, Armien et al. 20007, Oliveira et al. 2009) and Sida carpinifolia (Driemeier et al. 2000, Furlan et al. 2008). This behavior was observed in all animals throughout the experience, despite the weakness toward the end, even if they were lying down on the ground they ate and drank. Depression in these goats may be associated to partial or full agonist of lysergic acid derivatives by the neurotransmitter serotonin (Schiff 2006). The lysergic acid was described by some authors as toxic component of Ipomoea (Dalo \& Moussatché 1978, Sandoval et al. 2010). The intoxicated animals showed head tremor, nystagmus and abnormal facie, as has been reported in poisoning Ipomoea sp. (Oliveira et al. 2009), whereas in this study did not show opisthotonus cited by other authors (Armien et al. 2007). In our intoxicated animals, we observed that when they were transferred, the nervous signs relating to balance and postural positions were exacerbated. There was marked incoordination of the limbs and tendency to fall, coinciding with what is described by other authors (Oliveira et al. 2009). This could be explained by damage of the Purkinje cells. Thus, we assume that cerebellar damage was responsible for abnormal voluntary movements and lack of accuracy and coordination. Altered reflexes in intoxicated goats, showed an excessive response to sound stimuli. This may be due to the affection of the vestibulocochlear nerve, which connects the middle ear to the cerebellum. Lesions were also observed in the rostral colliculus, which are structures involved in the reflex response to sound, as well as participating in the visual reflex, nystagmus and other signs being observed in intoxicated animals as pointed by other authors (Armien at al. 2007, Oliveira et al. 2009).

Altered hypersensitive withdrawal, a typically defensive reflex against harmful stimuli, coincides with the lesions found in the thalamus, a structure that participates in consciousness to painful stimuli. These sign has been described by other authors; however it was not associated to the neuronal vacuolization (Armien et al. 2007, Pedroso et al. 2009). The defective reflex mentioned above, is also attributable to cerebellar lesions, reflecting lack of effective control of the flexor muscles. The observed bristled hair at the cervical region may also be associated with the response of nociceptive receptors regulated by the thalamus, which is also injured. Our results demonstrate the great variety of nervous signs displayed by Ipomoea poisoned goats. These signs are correlated with lesions in different parts of the CNS, being cerebellum and thalamus the most affected structures. Early diagnosis is essential to avoid major economic losses in goats. Besides, there are other poisonings or illnesses that cause alterations in the CNS and it is to identify the causes of the diseases and to establish a correlation with the clinical manifestations.

Acknowledgments.- This study was carried out in partial fulfillment of the requirements for the Ph.D. degree for EER. LACh, EJG and OCAP are Research Members of Consejo Nacional de Investigaciones Científicas y Técnicas (CONICET), Argentina.

\section{REFERENCES}

Adam S.E.I., Tartour G., Obeid H.M. \& Idris O.F. 1973. Effects of Ipomoea carnea on the liver and on serum enzymes in young ruminants. J. Comp. Pathol. 83:531-542,
Antoniassi N.A.B., Ferreira E.V., Santos C.E.P., Arruda L.P., Campos J.L.E., Nakazato L. \& Colodel E.M. 2007. Intoxicação espontânea por Ipomoea carnea subsp. fistulosa (Convolvulaceae) em bovinos no Pantanal Matogrossense. Pesq. Vet. Bras. 27:415-418.

Armién A.G., Tokarnia C.H., Peixoto P.V. \& Frese K. 2007. Spontaneous and experimental glycoprotein storage disease of goats induced by Ipomoea carnea subsp. fistulosa (Convolvulaceae). Vet. Pathol. 44:170-184.

Barbosa J.D., Oliveira C.M.C., Duarte M.D., Peixoto P.V. \& Tokarnia C.H. 2005. Intoxicação experimental e natural por Ipomoea asarifolia (Convolvulaceae) em búfalos e outros ruminantes. Pesq. Vet. Bras. 25:231-234.

Barbosa R.C., Riet-Correa F., Medeiros R.M.T., Lima E.F., Barros S.S., Gimeno E.J., Molyneux R.J. \& Gardner D.R. 2006. Intoxication by Ipomoea sericophylla and Ipomoea riedelli in goats in the state of Paraíba, Northeastern Brazil. Toxicon 47:371-379.

Barbosa R.C., Riet-Correa F., Lima E.F., Medeiros R.M.T., Guedes K.M.R., Gardner D.R., Molyneux R.J. \& Melo L.E.H. 2007. Experimental swainsonine poisoning in goats ingesting Ipomoea sericophylla and Ipomoea riedelli (Convolvulaceae). Pesq. Vet. Bras. 27:409-414.

Colegate S.M., Dorling P.R. \& Huxtable CR. 1979. A spectroscopic investigation of swainsonine: An alfa-mannosidase inhibitor isolated from Swainsona canescens. Aust. J. Chem. 32:2257-2264.

Daló N. \& Moussatché H. 1978. Acción tóxica de las plantas del género Ipomoea. Tarea común. 6, Universidad Centro Occidental, Caracas, p.25-39.

Damir H.A., Adam S. \& Tartour G. 1987. The effects of Ipomoea carnea on goats and sheep. Vet. Human Toxicol. 29:316-319.

De Balogh K.I.M., Dimande A.P., Van der Lugt J.J., Molyneux R.J., Naudé T.W. \& Welman W.G. 1999. A lysosomal storage disease induced by Ipomoea carnea in goats in Mozambique. J. Vet. Invest. 11:266-273.

Dorling, P.R., Huxtable, C.R. \& Colegate, S.M. 1980. Inhibition of lysosomal a-mannosidase by swainsonine, an indolizidine alkaloid isolated from Swainsona canescens. Biochem. J. 191:649-651.

Driemeier D., Colodel E.M., Gimeno E.J. \& Barros S.S. 2000. Lysosomal storage disease caused by Sida carpinifolia poisoning in goats. Vet. Pathol. 37:153-159.

Furlan F.H., Lucioli J., Veronezi L.O., Traverso S.D. \& Gava A. 2008. Intoxicação experimental por Sida carpinifolia (Malvaceae) em bovinos. Pesq. Vet. Bras. 28:57-62.

Guedes K.M.R., Riet-Correa F., Dantas A.F.M., Simões S.V.D., Miranda Neto E.G., Nobre V.T.M. \& Medeiros R.M.T. 2007. Doenças do sistema nervoso central de caprinos e ovinos no semi-árido. Pesq. Vet. Bras. 27:25-34.

Haraguchi M., Gorniak S.L., Ikeda K., Minami Y., Kato A., Watson A.A., Nash R.J., Molyneux R.J., \& Asano N. 2003. Alkaloidal components in the poisonous plants, Ipomoea carnea (Convolvulacea). J. Agric Food Chem. 51:4995-5000.

Hueza I.M., Dagli M.L., Gorniak S.L. \& Paulino C.A. 2003. Toxic effect of prenatal Ipomoea carnea administration to rats. Vet. Hum. Toxicol. 45:298302.

Idris O.F., Tartour G., Adam S.E.I. \& Obeid H.M. 1973. Toxicity of Ipomoea carnea. Trop. Anim. Health Prod. 5:119-123.

James LF, Panter KE. 1989. Locoweed poisoning in livestock. In: Swainsonine and Related Glycosidase Inhibitors, eds. James LF, Elbein AD, Molyneux RJ, and Warren CD, p.23-37. Iowa State University Press, Ames.

James L.F., van Kempen K.R. \& Harley W.J. 1970. Comparative pathology of Astragalus Astragalus (locoweed) and Swainsona poisoning in sheep. Vet. Pathol. 7:116-125.

Loretti A.L.P., Colodel E.M., Gimeno E.J. \& Driemeier D. 2003. Lysosomal storage disease in Sida carpinifolia toxicosis: An induced mannosidosis in horses. Equine Vet. J. 35:434-438.

Molyneux R.J. \& James L.F. 1982. Loco intoxication: Indolizidine alkaloids of spotted locoweed (Astragalus lentiginosus). Science 216:190-191.

Molyneux R., McKenzie R. \& O' Sullivan B. 1995. Identification of the glycosidase inhibitors swainsonine and calystegine $\mathrm{B}_{2}$ in weir vine (Ipomoea sp. (aff. Calobra) and correlation with toxicity. J. Nat. Prod. 58:878886. 
Nath I. \& Pathak D.C. 1995. Induced Ipomoea carnea toxicity in goats: clinical and pathomorphological studies. Ind. J. Vet. Pathol. 19:19-21.

Oliveira C.A., Barbosa J.D., Duarte M.D., Cerqueira V.D., Riet-Correa F. \& Riet-Correa G. 2009. Intoxicação por Ipomoea carnea subsp. fistulosa (Convolvulaceae) em caprinos na Ilha do Marajó. Pesq. Vet. Bras. 29:583-588.

Pedroso P.M.O., Von Hohendorf R., Oliveira L.G.S., Schmitz M., Cruz C.E.F. \& Driemeier D. 2009. Sida carpinifolia (Malvaceae) poisoning in fallow deer (Dama dama). J. Zoo Wildl. Med. 40:583-585.

Ralphs M.H., Panter K.E. \& James L.F. 1990. Feed preferences and habituation of sheep poisoned by locoweed. J. Anim. Sci. 68:1354-1354.

Riet-Correa F. \& Méndez M.D.C. 2007. Intoxicação por plantas e micotoxinas, p.99-219. In. Riet-Correa F., Schild A.L., Lemos A.A. \& Borges J.R. (Eds), Doenças de Ruminantes e Eqüídeos. Vol.2. 3aㅡ ed. Pallotti, Santa Maria. 694p.

Ríos E., Cholich L., Silva J. \& Acosta de Pérez O. 2008. Histopathological lesions in central nervous system of goats poisoned by Ipomoea carnea. Revta Vet. 19:130-134.

Rodriguez Armesto R., Repetto A.E., Ortega H.H., Peralta C.J., Pensiero J.F. \& Salvetti N.R. 2004. Intoxicación en cabras por ingestión de Ipomoea hieronymi var. calchaquina en la Provincia de Catamarca, Argentina. Vet. Arg. 21:332-341.
Sandoval E., Barrios M., Hernández C. \& Medina R. 2010. Study of the daily variation of the derivatives of ergolines in Ipomoea carnea. Revta Electr. Vet.. ISSN 1695-7504. Vol.11:3, 1-7.

Schiff P.L. 2006. Ergot and its alkaloids. Am. J. Pharmaceut. Educ. 70(5):110.

Schumaher-Henrique B., Gorniak S.L., Dagli M.L.Z. \& Spinosa H.S. 2003. The clinical, biochemical, haematological and pathological effect of long-term administration of Ipomoea carnea to growing goats. Vet Res. Commun. 27:311-319.

Srilatha C., Golpa-Naidu N.R. \& Rama-Rao P. 1993a. Haematological and biochemical studies in Ipomoea carnea plant toxicity in goats. J. Vet. Anim. Sci. 24:201-202.

Srilatha C., Golpa-Naidu N.R. \& Rama-Rao P. 1993b. Symptomatology of Ipomoea carnea plant toxicity in goats. J. Vet. Anim. Sci. 24:201-202.

Tartour G., Adam S.E.I., Obeid H.M. \& Idris O.F. 1974. Development of anemia in goats fed with Ipomoea carnea. Brit. Vet. J. 130:271-279

Tokarnia C.H., Döbereiner J. \& Peixoto P.V. 2000. Plantas Tóxicas do Brasil. Editora Helianthus, Rio de Janeiro, p.120-122.

Tokarnia C.H., Döbereiner J. \& Peixoto P.V. 2002. Poisonous plants affecting livestock in Brazil. Toxicon 40:1635-1660. 